Dokuz Eylül Üniversitesi-Mühendislik Fakültesi Fen ve Mühendislik Dergisi

Cilt 20, Sayı 59, Mayıs, 2018
Dokuz Eylul University-Faculty of Engineering Journal of Science and Engineering Volume 20, Issue 59, May, 2018

DOI: $10.21205 /$ deufmd. 2018205930

\title{
Electroless Cu Plating on ABS Plastic by Using Environmentally Friendly Chemicals
}

\author{
Canan URAZ ${ }^{*}$, Şenay MACI'T ${ }^{2}$ \\ ${ }^{1}$ Ege University, Engineering Faculty, Chemical Engineering Department 35100 \\ Bornova-İzmir, Turkey (ORCID: 0000-0002-9072-1420) \\ ${ }^{2}$ Ege University, Engineering Faculty, Chemical Engineering Department 35100 \\ Bornova-İzmir, Turkey (ORCID: 0000-0002-3568-4997)
}

(Alınış / Received: 23.02.2017, Kabul / Accepted: 28.03.2018,

Online Yayınlanma / Published Online: 15.05.2018)

Keywords

EMIC,

DCA,

ABS,

Metal plating,

Electroless

plating
Abstract: In this study, the electroless copper plating technique was applied on Acrylonitrile Butadiene Styrene (ABS) plastic. The effects of ionic liquid types, plating time and sanding paper size were investigated on plating. Experiments were carried out with two different types of ionic liquids: 1-ethyl-3-methyl imidazolium chloride (EMIC $\mathrm{C}_{6} \mathrm{H}_{11} \mathrm{~N}_{2} \mathrm{Cl}$ ) and 1-ethyl 3-methylimidazolium dicyanamide (DCA, $\mathrm{C}_{8} \mathrm{H}_{11} \mathrm{~N}_{5}$ ), with $120-500$ grit sandpapers by applying sand attrition process, at constant bath temperature as $60^{\circ} \mathrm{C}$, and with 30-150 minutes of deposition times. The characterization of the coated samples was performed by X-ray Diffraction (XRD) and Scanning Electron Microscopy (SEM). Experimental results show that the copper plating on ABS plastic was succeeded. The maximum amount of deposit was obtained by using EMIC as catalyst with 150 min deposition time and with 500 grit sandpaper size.

\section{Çevre Dostu Kimyasallar Kullanılarak ABS Plastik Üzerine Akımsız Bakır Kaplanması}

Anahtar Kelimeler Özet: Bu çalışmada Akrilonitril Bütadien Stiren (ABS) plastiği EMIC,

DCA,

ABS,

Metal kaplama,

Akımsız kaplama

üzerine akımsız bakır kaplama tekniği uygulanmıştır. İyonik sıvı çeşidinin, kaplama sıcaklığının, kaplama süresi ve zımpara kağıt boyutunun kaplama üzerine etkileri araștırılmıștır. Deneyler, 1etil-3-metil imidazolyum klorür (EMIC) ve 1-etil-3-metilimidazolyum dikyanamit (DCA) olmak üzere iki çeşit iyonik çözelti kullanılarak, 120-500 kum boyut aralığındaki zımpara kağıtları ile aşındırma işlemi uygulanarak, $60^{\circ} \mathrm{C}$ sabit banyo sıcaklığında, 30-150 dakika kaplama süresi ile gerçekleștirilmiștir. Kaplanan örneklerin karakterizasyonları X-ray Diffraction (XRD) ve Scanning Electron Microscopy (SEM) cihazlarıyla yapılmıştır. Deneylerden elde edilen sonuçlara göre ABS plastiği üzerine bakır kaplama tekniğinde bașarılı olunmuștur. En yüksek kaplama kalınlığı, katalizör olarak EMIC iyonik sıvısı kullanılarak, 150 dak. kaplama süresinde ve 500 kum boyutundaki zımpara kağıdı ile elde edilmiștir.

*Canan URAZ: canan.uraz@ege.edu.tr 


\section{Introduction}

$\mathrm{ABS}$ is a thermoplastic polymer made by polymerizing styrene and acrylonitrile in the presence of polybutadiene. The proportions can vary from 15 to $35 \%$ acrylonitrile, 5 to $30 \%$ butadiene and 40 to $60 \%$ styrene. Plating on ABS plastic materials provides a long term use of the plastics in applications. ABS plastic is an important chemical reagent an engineering material with high thermal stability, high mechanical strength and high resistance [1].

Some application areas for ABS are kitchen appliances, telephones, toys, the automotive and electric/electronic industries. Ionic liquids (ILs) are electrically conductive liquids composed merely of ions. Ionic liquids at room temperature (RTIL) are the salts having very low gas pressure or close to zero. Evaporation rate of ionic liquids is not high even if presence of catalyst or solvent at high temperature. They have a wide liquid range, and are very stable at high temperature. EMIC, 1-ethyl-3-methyl imidazolium chloride $\left(\mathrm{C}_{6} \mathrm{H}_{11} \mathrm{~N}_{2} \mathrm{Cl}\right)$ and DCA, 1-ethyl 3methylimidazolium dicyanamide $\left(\mathrm{C}_{8} \mathrm{H}_{11} \mathrm{~N}_{5}\right)$ are now widely used as a cationic source for low temperature molten salts. For instance 1-ethyl 3methyl imidazolium trifloromethylsufonit has a liquid range of $471^{\circ} \mathrm{C}$ with melting point $-15^{\circ} \mathrm{C}$ and deformation temperature $455^{\circ} \mathrm{C}$ [2]. The characteristic make RTILs applicative for reactions [3].

The improvement effect of RTIL on the plating were observed on the research studies. The $\mathrm{pH}$ adjustment ability of RTIL leads to positive effect on plating. Kouro et al. (2008)and Ming-Jay et al.(2008) performed aluminum and nickel plating with ionic liquids, respectively $[4,5]$.
Electroless plating is the main part of the electroplating process. In this part plastic material has a conductive behavior. It provides homogeneous distribution, durability and preferred thickness. It is nonmagnetic and because of the higher stretching ratio there is no break into pieces under distortion or elongation. The difference of the electroless plating from the electroplating is about energy. Electroless plating does not need electrical energy. So the plating film appears with uniform structure. This method is widely used because of superior features such as providing uniform surface film and resistance of abrasion and corrosion. At related studies, catalysts and activation solutions for the electroless bath are mainly consisting of colloidal suspension of palladium metal and tin ions. The function of the bath is precipitating colloidal palladium (palladium-tin) on the porous $\mathrm{ABS}$ surface. Palladium is used as catalyst and the nickel and copper electroless precipitation reaction is begun. Two metals (nickel and copper) are most widely used metals at the decorative plating of the plastics [6-8]. Electroless metal plating technique begins to apply by using catalyst. Many researchers have attempted to deposit metals by using electroless plating technique. For example, electroless nickel and copper plating was obtained over carbon nanotubes and graphite at previous studies [6, 9]. Fukuhara and coworkers implemented electroless plating process by preparing copper surface catalysts [10]. At the another study, Song and friends coated silver by using nickel phosphite catalyst [11]. The surface characterization of the activated ABS plastic was obtained by using Scanning Electron Microscopy (SEM) and $\mathrm{Ni}$ coating was also characterized by X-Ray diffraction (XRD) [1]. 
The aim of this study was to investigate and to develop of electroless plating catalyst and activation solution in the electroplating industry. For this purpose an electroless plating bath had prepared by using environmentally friendly chemicals (EMIC \& DCA) for copper plating process on ABS plastic. On the contrary of the traditional processes, the etching and the plating processes were performed with environmentally friendly chemicals. Unlike the electroless nickel plating on metal substrate, the process on ABS substrate is not auto-catalytic. Hence, etching and activation are necessary for initiating the process. The final coating is then investigated using scanning electron microscope (SEM) together with energy dispersive spectroscopy (EDS) and x-ray diffraction (XRD) analysis to identify the morphology and structure of the coating. The SEM \& EDS analysis on surface and chemical composition of model surface after each preliminary surface treatment are also presented.

\section{Material and Method}

The copper plating on ABS plastic material experiments were performed in fume hood at atmospheric pressure and room temperature.

The possible overall reactions for electroless copper deposition were:

$$
\begin{aligned}
\mathrm{Cu}^{2+}+2 \mathrm{HCHO}+ & 4 \mathrm{OH}^{-} \\
& \rightarrow \mathrm{Cu}+2 \mathrm{HCOO}^{-}+2 \mathrm{H}_{2} \mathrm{O}+\mathrm{H}_{2} \\
\mathrm{HCHO}+2 \mathrm{OH}^{-} \rightarrow & \mathrm{HCOO}^{-}+\mathrm{H}_{2} \mathrm{O}+\frac{1}{2} \mathrm{H}_{2} \mathrm{O}+e^{-}
\end{aligned}
$$

The experiments consist of four steps: preparing the chemicals and materials, etching, plating and the analysis of samples. The investigated parameters were sandpaper size, plating time and effects of ionic liquid types (RTIL).

Previously, $20 \mathrm{~mm}$ x $30 \mathrm{~mm}$ x $1.5 \mathrm{~mm}$ ABS plastic samples were grounded with the 120, 240, 320 and 500 grit sandpaper size. Roughness is providing to a good mechanical bonding on the material surface. Then the samples were placed in a $75^{\circ} \mathrm{C}$ oven maintained for 4 to $5 \mathrm{~h}$ to remove stress. The samples were removed from the oven and they were placed in a $10 \mathrm{~g} / \mathrm{L} \mathrm{NaOH}$ alcoholic solution. This solution was placed into in a $35-40{ }^{\circ} \mathrm{C}$ water bath for $30 \mathrm{~min}$. It was placed in an aqueous solution with 250-300 mL/L nitric acid, 0.4-0.6 mL/L hydrogen peroxide and 2-4 g/ $\mathrm{L} \mathrm{NH}_{4} \mathrm{~F}$. Then it was placed in the supersonic bath[12]. The function of the supersonic bath is precipitating the solution on porous surface. The filling of all pores on surface was obtained by using 40 $\mathrm{kHz}, 100 \mathrm{~W}$ supersonic waves for 30 min. In the literature, this operation is expressed "non-noble metal activation pretreatment" [12]. After this operation the precipitation reaction appeared. Then the samples were washed with deionized water.

At the second step, the material pretreatment solution of $\mathrm{CuCl}_{2}$ for copper plating and RTIL (EMIC or DCA) were prepared with the molar ratio $2: 1$ and the samples were immersed in the ionic solution and it was left for a week [4].

At the plating step, the samples were placed at $60^{\circ} \mathrm{C}$ water bath containing the plating solution prepared with the copper sulfate pentahydrate, ethylenediaminetetraacetic acid tetra sodium salt (EDTA), formaldehyde and 2,2-dipyridyl. The composition of the electroless plating bath can be seen from Table 1. 
Table 1. Composition of the Electroless Copper Plating Bath

\begin{tabular}{|c|l|c|}
\hline Formula & Chemical & $\begin{array}{c}\text { Conc. } \\
\text { (g/L) }\end{array}$ \\
\hline $\mathrm{CuSO}_{4} 5 \mathrm{H}_{2} \mathrm{O}$ & Copper Sulfate & $12-15$ \\
\hline $\mathrm{C}_{10} \mathrm{H}_{14} \mathrm{~N}_{2} \mathrm{Na}_{2} \mathrm{O}_{8}$ & EDTA-2Na & $40-45$ \\
$2 \mathrm{H}_{2} \mathrm{O}$ & & \\
\hline $\mathrm{C}_{10} \mathrm{H}_{8} \mathrm{~N}_{2}$ & $2,2-$ Dipyridyl & $0.04-$ \\
& & 0.05 \\
\hline $\mathrm{CH}_{2} \mathrm{O}$ & Formaldehyde & $20-25$ \\
\hline
\end{tabular}

The $\mathrm{pH}$ value of the copper plating solution was adjusted as 8-9 by adding $\mathrm{NaOH}$ step by step. During the plating reaction, numerous bubbles were observed.

Finally, the resultant copper plated samples were washed by deionized water, and then they were placed in a $45^{\circ} \mathrm{C}$ oven to dry.

The final coating was then investigated using scanning electron microscope (SEM/JEOL-JSM 6060-2003) together with energy dispersive spectroscopy (EDS) to identify the morphology and structure of the coating. All specimens were coated with $\mathrm{Au}$ for SEM \& EDS analysis on surface and chemical composition of model surface after each preliminary surface treatment were also presented. The plated specimens were qualitatively identified by X-ray diffraction (XRD / RIGAKU D Max 2200 PC, $\mathrm{Cu} \mathrm{K \alpha}$ ). Its characteristic peaks were observed at 2 theta $(2 \theta)=$ $45^{\circ}, 50^{\circ}$, and $75^{\circ}$.

\section{Results and Discussion}

There was no harmful chemical used at the preliminary preparation of ABS plastic samples on the contrary of the traditional etching processes. Instead of using hazardous chemical like palladium and concentrated acid such as sulphuric acid, ethyl alcohol and sandpaper were utilized. Considering process safety and environmental concerns, palladium-free plating is a better choice and is strongly in demand now.
The amounts of deposit on the ABS plastics were determined by using Fischerscope X-Ray XDL-B System, and the surface of the copper plated plastics was also analyzed through XRD and SEM.

Results obtained from X-Ray analysis were evaluated and thickness versus sandpaper size graph was plotted. It is shown from Figure 1 that, the thickness of the copper film increases when sandpaper size increases by using EMIC. The maximum amount of the deposit was about $6.67 \mu \mathrm{m}$ for 500 grit of sand paper. Although sandpaper size increases, increase in the thickness of the copper film could not be obtained by using DCA. The maximum amount of the deposit was found as $1.5 \mu \mathrm{m}$ for the same operating conditions by using DCA(Figure 2).

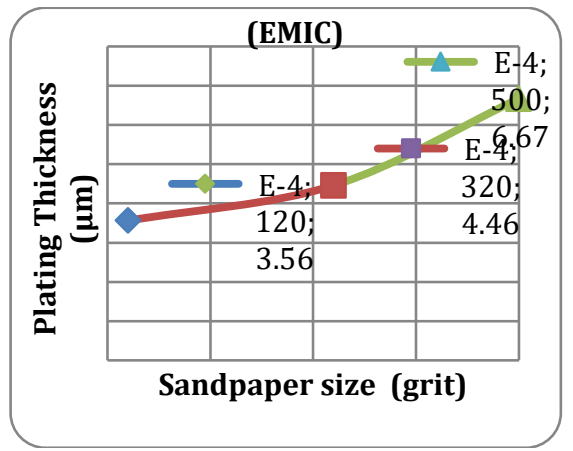

Figure 1. Effect of sandpaper size on plating thickness at constant plating time (150 $\mathrm{min}$ ) for EMIC.

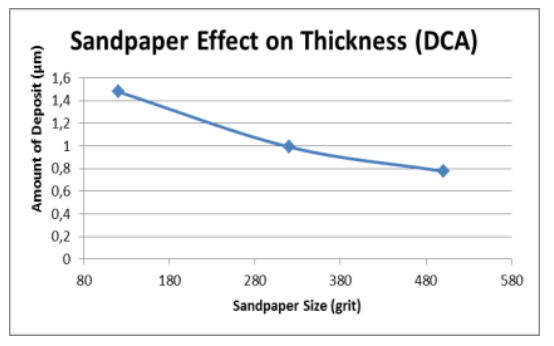

Figure 2. Effect of sandpaper size on plating thickness at constant plating time (150 $\mathrm{min})$ for DCA. 
Figure 3 shows that the XRD patterns of copper plating. It also reveals the absence of other elements' diffraction peaks, which states that the plating only includes $\mathrm{Cu}$ with using EMIC. According to the literature, the results of XRD analysis was obtained as expected [12]. Diffraction peaks was obtained at approximately 45, 50, and $752 \theta$ degrees.

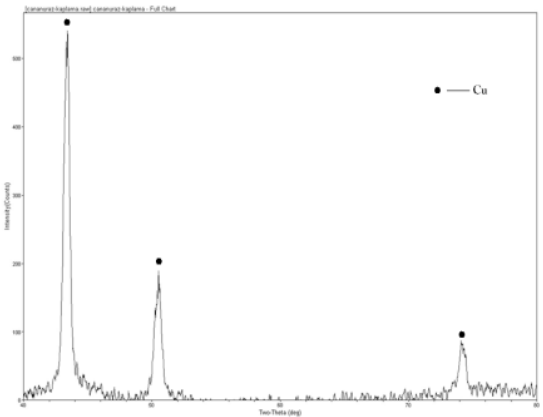

Figure 3. XRD analysis of copper plated ABS plastic.

The dependence of plating time on the amount of deposit was also investigated for both ionic liquids. It can be seen from the Figure 4 that the amount of deposit increased with increasing plating time of the substrate for EMIC at constant temperature $\left(60^{\circ} \mathrm{C}\right)$. Although the amount of deposit increased with increasing plating time of the substrate for DCA, the expected results were not obtained at experiments with DCA. Because the maximum amount of the deposit was found as $1.00 \mu \mathrm{m}$ for 150 min by using DCA (Figure 5). The reason for the inefficiency of DCA may come from the structure differences between EMIC and DCA.

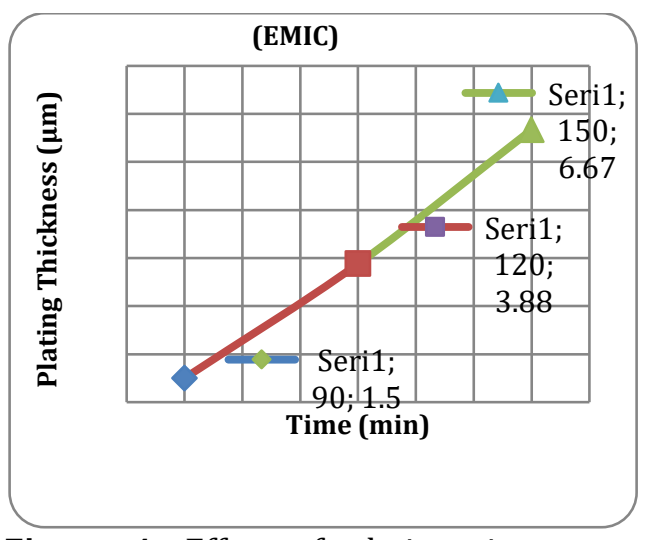

Figure 4. Effect of plating time on plating thickness at constant sandpaper size (500 grit) for EMIC.

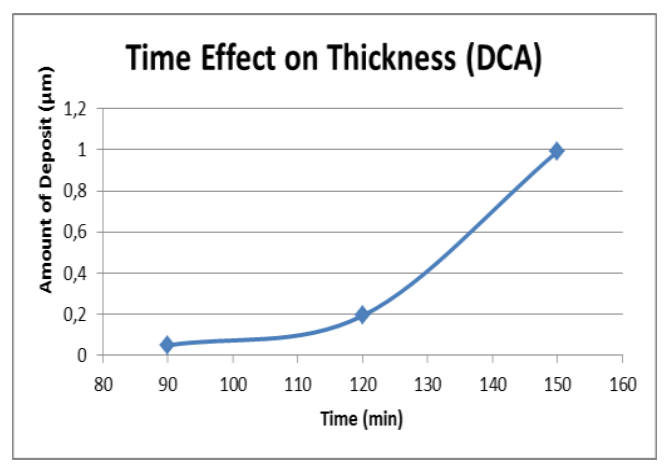

Figure 5. Effect of plating time on plating thickness at constant sandpaper size (500 grit) for DCA.

It is obtained from the results of SEM analysis that, a crystalline material was deposited on the surface of the substrate and it is proved that electroless plating took place. And also, the copper was homogeneously distributed on the surface of the film. It can be seen from Figure 6 and Figure 7. 


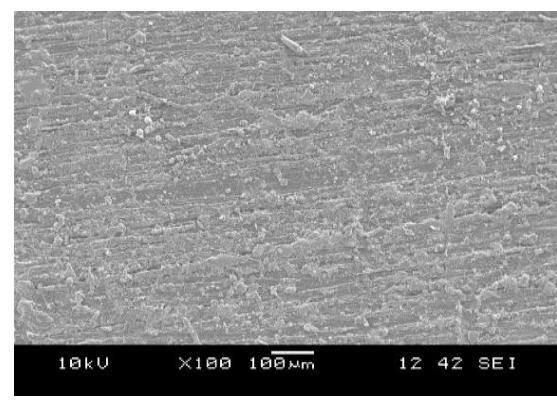

Figure 6. SEM Analysis of sample which obtained by using EMIC with 500 grit size sandpaper at 150 minutes.

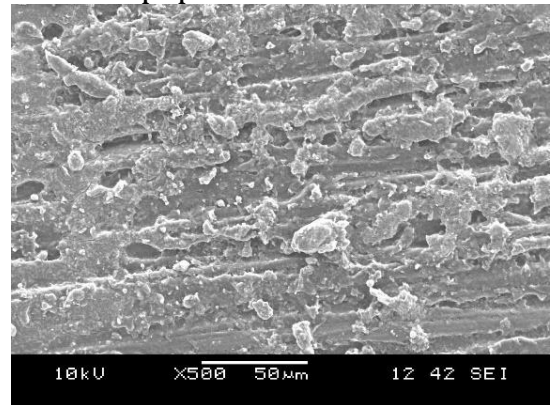

Figure 7. SEM Analysis of sample which obtained by using EMIC with 500 grit size sandpaper at 150 minutes.

According to SEM-EDS analysis results (Table 2), the elemental mapping result, the plating film consisted of copper only, because only copper was detected from the surface of the boundary between copper substrate and the deposit.

Table 2. SEM-EDS analysis results of sample which is obtained by using EMIC with 320 grit size sandpaper at 150 minutes.

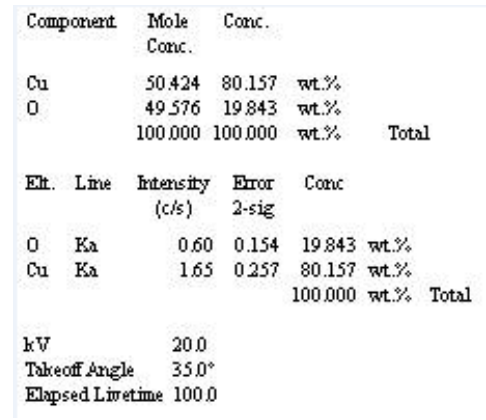

\section{Conclusion}

As a result, it is concluded that EMIC is more suitable ionic liquid then DCA type ionic liquid as catalyst for electroless copper plating on ABS plastic. Consequently the maximum amount of deposit is obtained in the sample in which EMIC is used as catalyst with 150 min deposition time and 500 grit sandpaper size. SEM results indicated that the plated film consisted of copper only, and the copper was homogeneously distributed on the surface of the film.

\section{Acknowledgment}

The authors would like to thank TKF Metal Co. to their contribution with the performing analyses at Fischerscope XRay XDL-B System.

\section{References}

[1] Tang, X., Bi, C., Han, C., Zhang, B. 2009. A New Palladium Free Surface Activation Process for $\mathrm{Ni}$ Electroless Plating on ABS Plastic, Materials Letters, 63, 840-842, DOI:10.1016/j.matlet.2009.01.006.

[2] Ngo, H.L., LeCompte, K., Hargens, L., McEwen, A.B., 2000. Thermal properties of imidazolium ionic liquids, Thermochimica Acta, 357 358, 97-102, PII: S 00406031(00)00373-7.

[3] Murugesan,S. ve Linhardt, R.J., 2005. Ionic liquids in carbohydrate chemistry-current trends and future directions, Current Organic Synthesis, 2, 437-451, DOI: 1570 1794/05.

[4] Koura, N., Nagase, H., Sato, A., Kumakura, S., Takeuchi, K., Ui, K., Tsuda, T., Loong, C. K. 2008. Electroless Plating of Aluminum from a Room-Temperature Ionic Liquid Electrolyte, Journal of Electrochemical Society, 155, 155157, IP 130.203.136.75. 
[5] Deng Ming-Jay, I.-Wen Sun, Po-Yu Chen, Jeng-Kuei Chang,Wen-Ta Tsai, 2008. Electrodeposition behavior of nickel in the waterand air-stable 1-ethyl-3methylimidazolium-dicyanamide room-temperature ionic liquid, Electrochimica Acta, 53, 58125818,DOI: $10.1016 /$ j.electacta. 200 8.03.040.

[6] Ang, L.L., Hor, T. S. A., Xu, G. Q., Tung, C. H., Zhao, S.P., Wang, J. L.S. 2000. Decoration of Activated Carbon Nanotubes with Copper and Nickel, Carbon, 38, 363-372, DOI:10.1016 / S0008-6223 (99) 00112-8.

[7] Liu, Z., Chen, Y. 1998. Spectroscopic Studies on Tetragonal $\mathrm{ZrO}_{2}$ Supported $\mathrm{MoO}_{3}$ and $\mathrm{NiO}-\mathrm{MoO}_{3}$ Systems, Journal of Catalysis, 177, 314-324, DOI: 0021-9517/98.

[8] Rudnik, E., Kokoszka, K., Łapsa, J. 2008. Comparative Studies on the Electroless Deposition of Ni-P, Co-P and Their Composites with $\mathrm{SiC}$ Particles, Surface \& Coatings Technology, 202, DOI: 2584-2590, 10.11118/actaun201664051459.

[9] Caturla, F., Molina, F., Molina-Sabio, M., Rodriguez-Reinoso, F., Esteban, A. 1995. Electroless Plating of Graphite with Copper and Nickel, Journal of Electrochemical Science, 142, 4084-4091, ISSN 1452-3981.

[10] Fukuhara, C., Ohkura, H., Gonohe, K., Igarashi, A. 2005. LowTemperature Water-Gas Shift Reaction of Plate-Type CopperBased Catalysts on an Aluminum Plate Prepared by Electroless Plating, Applied Catalysis A: General, 279, 195-203, DOI: 10.1016/j.apcata.2004.10.036.

[11] Song, L., Li, W., Wang, G., Zhang, M., Tao, K. 2007. A New Route to Prepare Supported Nickel Phosphide/Silica-Alumina Hydrotreating Catalysts from Amorphous Alloys, Catalysis
Today, 125, 137-142, DOI:10.1016/j.cattod.2007.02.033.

[12] Luo, L., Lu, Z., Huang, X., Tan, X., Ding, X., Cheng, J., Zhu, L., Wu, Y. 2014. Electroless Copper Plating on PC Engineering Plastic with a Novel Palladium-Free Surface Activation Process, Surface \& Coating Technology, 251, 69-73, DOI:10.1179/1743294414Y.00000 00387. 